\title{
The association between serum testosterone levels and cognitive function of men aged 50 years or more
}

\author{
Eka Julianta Wahjoepramono \\ UPH Medical School - Siloam Hospitals, Lippo Karawaci, Tangerang, Indonesia
}

\begin{abstract}
Abstrak
Tujuan Proses penuaan merupakan faktor risiko utama terjadinya penyakit degeneratif, termasuk gangguan kognitif. Sejumlah studi menjelaskan bahwa terdapat hubungan antara penurunan fungsi kognitif dengan kadar testosteron yang rendah. Studi ini bertujuan untuk mengetahui hubungan antara kadar testosteron dan fungsi kognitif pada lakilaki yang sudah memperlihatkan penurunan kognitif ringan.

Metode Penelitian ini merupakan studi potong lintang pada laki-laki usia di atas 50 tahun di klinik Neuroscience Siloam Hospitals, Lippo Karawaci, Tangerang antara tahun 2002-2004. Subyek penelitian merupakan pasien yang merasa mengalami penurunan fungsi kognitif. Penilaian fungsi kognitif dilakukan dengan menggunakan 30 butir pertanyaan Mini-Mental State Examination (MMSE). Kadar testosteron diukur secara ELFA (Enzyme Linked Fluorescent Assay).

Hasil Dalam penelitian ini berhasil direkrut 112 orang subyek penelitian, dengan median usia 64 tahun. Sebanyak 101 orang menjalani pemeriksaan fungsi kognitif dan pemeriksaan kadar testosteron. Rerata skor MMSE adalah 26 \pm 3.2 , sedangkan rerata kadar testosteron adalah $14.7 \pm 5.72 \mathrm{nmol} / \mathrm{L}$.

Kesimpulan Tidak ada korelasi yang signifikan antara skor MMSE dan kadar testosteron (r=0,038). Penelitian ini menunjukkan bahwa pada laki-laki berusia 50 tahun ke atas dengan keluhan penurunan kognitif memiliki penurunan skor MMSE tetapi memiliki kadar testosteron dalam batas yang normal. Tidak ditemukan adanya korelasi antara skor MMSE dan kadar testosteron, hal ini mungkin disebabkan karena sebagian besar pasien telah memiliki kadar testosteron yang rendah. (Med J Indones 2009; 18: 36-40)
\end{abstract}

\begin{abstract}
Aim The Aging process is a major risk factor for the development of degenerative diseases, including cognitive impairment. Many studies have shown that reduced cognitive function is associated with low testosterone levels. This study was aimed to know the association between serum testosterone level and cognitive functions in men who showed mild cognitive impairment.

Method This was a cross-sectional study in men aged 50 years or more in Neuroscience Clinic Siloam Hospitals, Lippo Karawaci, Tangerang between 2002 and 2004. Subjects were patients who complained of decreasing cognitive function. Cognitive function was assessed by using the 30-point Mini-Mental State Examination (MMSE) questionnaires. Testosterone level was measured by using the enzyme-linked fluorescent assay (ELFA) method.

Results A total of 112 men were recruited during the study period. The median age was 64 years old. One-hundred and one subjects underwent cognitive function test and serum testosterone assay. The mean MMSE score was $26 \pm 3.2$ points, whereas the mean testosterone level was $14.7 \pm 5.72 \mathrm{nmol} / \mathrm{L}$

Conclusion There was no significant correlation between the MMSE score and testosterone level $(\mathrm{r}=0,038)$. This study showed that men aged 50 years and above with symptoms of declined cognitive function have decreasing MMSE scores but were still within the normal range of testosterone levels. No correlation was found between MMSE scores and testosterone levels since most subjects were eugonadal. (Med J Indones 2009; 18: 36-40)
\end{abstract}

Keywords: Testosterone, Cognitive function

The process of aging is a major risk factor for the development of illnesses after the age of 28 years in developed countries which cause mortality, such as cardiovascular, cancer, and neurodegenerative disease such as senile dementia and Alzheimer disease. ${ }^{1}$ Severe cognitive impairment (such as Alzheimer's disease) is one of the predictive factors of mortality at older ages. ${ }^{2}$ A transitional condition between normal aging process and Alzheimer's disease is mild cognitive impairment (MCI). The prevalence of MCI is estimated between 3 and $20 \%$ in adult population aged 75 years or more. ${ }^{3}$ 
Recently, low serum testosterone concentrations was thought to play an important role in age-associated cognitive impairment. ${ }^{4,5,6}$ In blood, testosterone is mainly bound to its carrier protein, i.e. the sex-hormone binding globulin (SHBG). However, its active form is the bioavailable testosterone or free testosterone. The total and free testosterone levels represent the concentration of bioactive hormones in a man. ${ }^{7}$

In elderly men, reduced testosterone production and increased SHBG cause hypogonadism. The administration of testosterone replacement therapy is frequently considered to treat hypogonadism in men as an equivalent of hormone replacement therapy in postmenopausal women. However, there is concern about giving exogenous testosterone which may promote hyperplasia or even adenocarcinoma of the prostate. One study has found that there is no difference of prostate volume or prostate-specific antigen (PSA) between hypogonadal men receiving testosterone and normal control, ${ }^{8}$ but another study found significant increase of PSA level in elderly men receiving testosterone treatment. ${ }^{9}$

Several studies have tried to explain the association between serum testosterone level and cognitive ability in young adults, with varying results. ${ }^{10,11,12}$ Furthermore, many studies have shown that low endogenous testosterone is associated with impaired cognitive ability which could be partly restored by administering exogenous testosterone. Therefore, measuring serum testosterone concentration should be considered in men with cognitive impairment. ${ }^{13}$ This study was aimed to know the association between testosterone concentration and cognitive function in men who have already shown mild cognitive impairment.

\section{METHOD}

\section{Study design and subjects}

This was a cross-sectional study in men aged 50 years or above in Siloam Hospital, Lippo Karawaci, Tangerang. The study population were male patients in Neuroscience Clinic complaining of decreased cognitive function. The study subjects were patients who came between 2002 and 2004 , recruited by purposive sampling method.

\section{Assessment of cognitive function}

The assessment of cognitive function was done by using the 30-point Mini-Mental State Examination (MMSE) questionnaire including orientation (time and place), memory, concentration, language, and praxis. Respondents were asked to spell the word "WORLD" backward (D-L-R-O-W) and counting down from 100 in blocks of 7. The scores from each question were summed to get the total MMSE score. The Higher the score, the better the cognitive ability.

\section{Serum Testosterone Measurement}

Blood sample $(10 \mathrm{~mL})$ was taken ready from every subject and was stored at $-70^{\circ} \mathrm{C}$ until it was ready for assay. Measurement was done in the Clinical Pathology Laboratory, Siloam Hospital. Total serum testosterone concentration was measured by using enzyme-linked fluorescent assay (ELFA) method with VIDAS ${ }^{\circ}$. The normal reference value in normal adult men was 8-35 $\mathrm{nmol} / \mathrm{L}$.

\section{Data analysis}

Characteristics of the study subjects were analyzed descriptively to see the distribution pattern. Bivariate analysis was done to know the correlation between total MMSE score and testosterone levels (Pearson correlation). Data analysis was done using statistical software, SPSS version 13.0 for Windows PC (SPSS Inc, Chicago, Illinois).

\section{RESULTS}

A total of 112 study subjects were recruited between 2002 and 2004 based on the study criteria. The mean age of the patients was $64.8 \pm 7.89$ years, ranging from 50 to 91 years. The median age was 64 years. About half of the study subjects were between 60 and 70 years old (Table 1). Distribution of the study subjects was tested with Kolomogorov-Smirnov test and showed a normal pattern $(p=0.200)$ although there were several extreme values (Figure 1).

Table 1. Characteristics of the study subjects

\begin{tabular}{lcc}
\hline Variable & $\mathbf{N}$ & $\mathbf{\%}$ \\
\hline Age group & & \\
<55 & 8 & 7.1 \\
55-59 years & 18 & 16.1 \\
60-70 years & 58 & 51.8 \\
> 70 years & 23 & 20.5 \\
Total data & 5 & 4.5 \\
Education level & 112 & 100.0 \\
- Primary school & & \\
- Secondary school & 41 & 14.3 \\
Tertiary school & 55 & 36.6 \\
Total & 112 & 49.1 \\
\hline
\end{tabular}




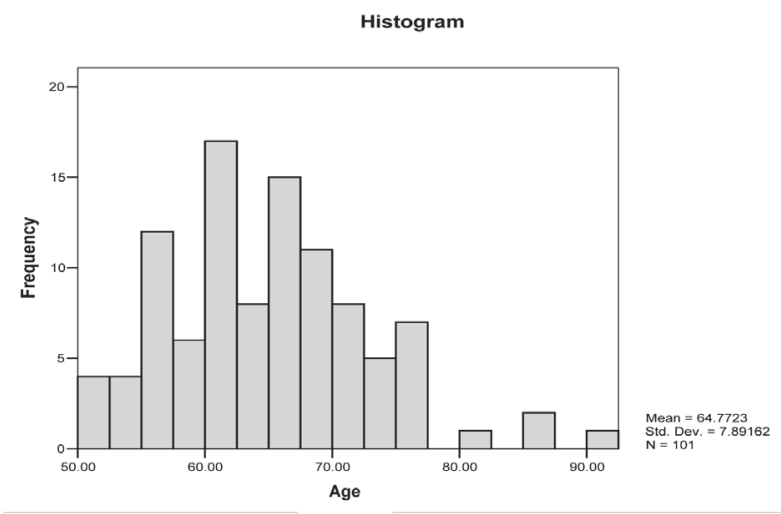

Figure 1. Age distribution of the study subjects

One-hundred and one subjects underwent cognitive function test using MMSE questionnaires, measurement of serum testosterone and prostate tumor marker, i.e. the prostate specific antigen (PSA) concentrations. The mean and distribution of each variable is given in Table 2. Data normality using Kolmogorov-Smirnov test showed that the distribution of MMSE score was abnormal $(p<0.0001)$, i.e. shifted to the right. There were $81(81 \%)$ patients who scored 25 or more, 38 (37.6\%) among them had 28-30 scores (Figure 2). Serum testosterone concentrations showed normal distribution pattern $(\mathrm{p}=0.200)$ with Kolmogorov Smirnov test (Figure 3).

Table 2. Cognitive function, testosterone and prostate-specific antigen (PSA) levels

\begin{tabular}{lcccc}
\hline Variable & Mean & $\begin{array}{c}\text { Standard } \\
\text { Deviation }\end{array}$ & Minimum & Maximum \\
\hline MMSE Score & 26 & 3.2 & 7 & 30 \\
$\begin{array}{l}\text { Testosterone } \\
\text { level (nmol/L) }\end{array}$ & 14.7 & 5.72 & 0.35 & 34.42 \\
$\begin{array}{l}\text { PSA level } \\
\text { (ng/mL) }\end{array}$ & 1.8 & 2.54 & 0.02 & 23.29 \\
\hline
\end{tabular}

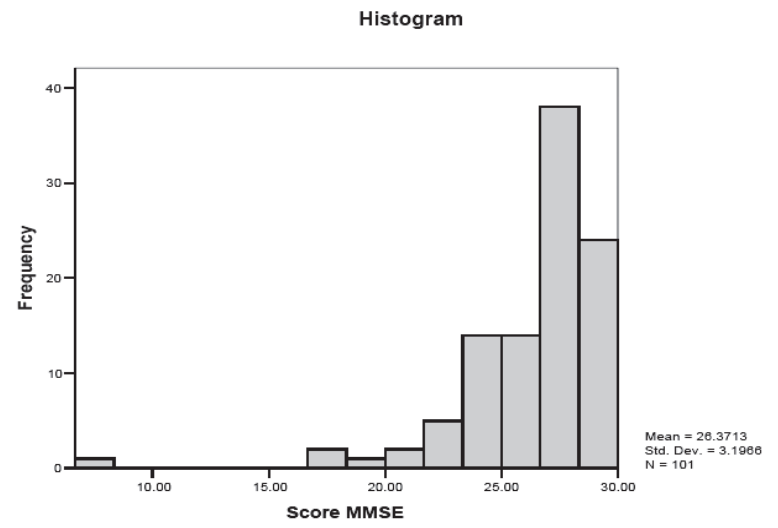

Figure 2. Distribution of MMSE Scores

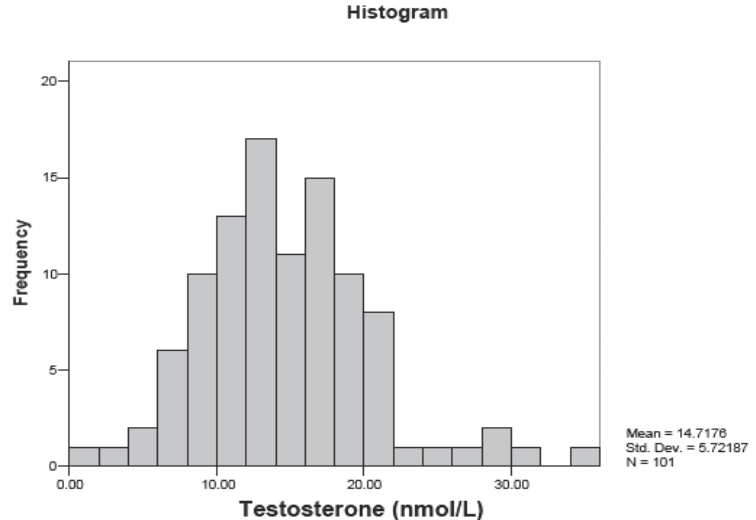

Figure 3. Distribution of serum testosterone concentration (nmol/L)

Correlative analysis between cognitive factor and other study variables showed a weak positive correlation between MMSE score and educational level (positive correlation) but a weak negative correlation between MMSE score and educational level. The higher the MMSE score, the higher the educational level but the age group is lower. No significant correlation was found between MMSE score and testosterone or PSA concentrations (Table 3 ).

Table 3. Correlation between MMSE scores and other study variables

\begin{tabular}{lcc}
\hline Variable & $\begin{array}{c}\text { Pearson correlation } \\
(\mathbf{r})\end{array}$ & p value \\
\hline Age group & -0.235 & 0.015 \\
Education & 0.235 & 0.014 \\
Testosterone level (nmol/L) & 0.038 & 0.694 \\
PSA level $(\mathrm{ng} / \mathrm{mL})$ & -0.091 & 0.358 \\
\hline
\end{tabular}

\section{DISCUSSION}

Studies on the hormonal aspects (testosterone) of cognitive function in Indonesia are still very limited. This research was a preliminary study on the profile of cognitive function and its association with testosterone concentration among men aged 50 years or more who have mild cognitive impairments.

Cognitive function assessed by MMSE showed that most patients had scored more than 24 points, but the average was less than the normal value (30 points). It means that most subjects have already suffered from mild cognitive impairments. Generally, the MMSE score is categorized into 4 groups, i.e. normal (28-30), mild (24-27), moderate (19-23) and severe (0-18). ${ }^{15}$ 
This classification was chosen because it represents the degree of cognitive dysfunction and is frequently used in epidemiological studies. According to this classification, most of the patients $(63.3 \%)$ already had impaired cognitive function. There were only 38 patients who were categorized as normal.

In this study, no correlation was found between cognitive function (MMSE score) and testosterone level. This could be due to the fact that most subjects were still within normal serum testosterone concentrations range. One study had used the testosterone concentration below $11.3 \mathrm{nmol} / \mathrm{L}(325 \mathrm{ng} / \mathrm{dL})$ or free testosterone index (testosterone/SHBG) less than $0.153 \mathrm{nmol} / \mathrm{nmol}$ as cutoff points for hypogonadism. ${ }^{16}$

A longitudinal study in 547 men aged 59-89 years showed that the free testosterone level was correlated to the better memory test, but not with the MMSE score which showed more complex association. ${ }^{17}$ Another study in 310 men aged 50 years or more found that the free testosterone concentration was positively correlated with general cognitive score ability. Men with higher free testosterone concentration had higher cognitive scores $(p<0.001)$, but it is not the case with total testosterone concentration. ${ }^{18}$

A recent study involving 70-year old men or more also did not show a significant difference if total testosterone concentration between respondents with standardized MMSE (SMMSE) score $\leq 25$ points and $\geq 20$ points ( 14.8 versus $15.2 \mathrm{nmol} / \mathrm{L} ; \mathrm{p}=0.118$ ). However, between those SMMSE groups, there was a significant difference of free testosterone level (262 versus $278 \mathrm{pmol} / \mathrm{L}$; $\mathrm{p}=0.003)$ and luteinizing hormone concentration (4.7 versus $4.1 \mathrm{IU} / \mathrm{L} ; \mathrm{p}<0,001)$. These results suggested that it is the free testosterone concentration, that plays a role in cognitive function of elderly men. ${ }^{19}$

This current study did not assess the free testosterone concentration. The reasons were because the procedure to measure free testosterone concentration is more difficult and also costs higher than total serum testosterone concentration. However, free testosterone measurement could be recommended in patients with mild cognitive impairment or androgen deficiency in aging males needing testosterone replacement therapy. For this purpose, an assay of PSA as a screening tool for prostate cancer is needed since prostate malignancy could be aggravated by administering exogenous testosterone. In this study, there was a weak correlation $(r=0.273)$ but significant $(\mathrm{p}=0.004)$ between total testosterone and PSA concentrations (data was not presented).

\section{CONCLUSION}

In this current study, men aged 50 years and above with symptoms of cognitive impairment did show decreasing MMSE score. However, this study fails to show any association between the MMSE score and testosterone level which might be due to the fact that most of the study subjects were eugonadal. Further study is needed to confirm this finding by measuring the freetestosterone level, especially whenever testosterone replacement therapy is being considered.

\section{REFERENCES}

1. Harman D. Aging: phenomena and theories. Ann NY Acad Sci. 1998;854:1-7.

2. Bassuk SS, Wypij D, Berkman LF. Cognitive impairment and mortality in the community-dwelling elderly. Am J Epidemiol. 2000;151:676-88.

3. Busse A, Bischkopf J, Riedel-Heller SG, Angermeyer MC. Mild cognitive impairment: prevalence and incidence according to different diagnostic criteria. Br J Psychiatry. 2003;182:449-54.

4. Moffat SD.Effects of testosterone on cognitive and brain aging in elderly men. Annals of the New York Academy of Sciences, 2005;1055:80-92.

5. Hogervorst E, Bandelow S, Moffat SD. Increasing testosterone levels and effects on cognitive functions in elderly men and women: a review. Curr Drug Targets. CNS Neurol Dis. 2005;4:531-40.

6. Janowsky JS. The role of androgens in cognition and brain aging in men. Neurosci. 2006; 138:1015-20.

7. Van den Beld AW, de Jong FH, Grobbee DE, Pols HAP, Lamberts SWJ. Measures of bioavailable serum testosterone and estradiol and their relationship with muscle strength, bone density, and body composition in elderly men. J Clin Endocrinol Metab. 2000;85:3276-82.

8. Behre HM, Bohmeyer J, Nieschlag E. Prostate volume in testosterone-treated and untreated hypoganadal men in comparison to age-matched normal controls. Clin Endocrinol (Oxf). 1994;40:341-9.

9. Tenover JS. Effects of testosterone supplementation in the aging male. J Clin Endocrinol Metab. 1992;75:1092-8.

10. Gordon HW, Lee PA. A relationship between gonadotropins and visuospatial function. Neuropsychologia 1986;24:563-76.

11. Silverman I, Kastuk D, Choi J, Phillips K. Testosterone levels and spatial ability in men. Psychoneuroendocrinol 1999;24:813-22.

12. Muller M, Aleman A, Grobbee DE, de Haan EHF, van der Schouw YT. Endogenous sex hormone levels and cognitive function in aging men. Is there an optimal level? Neurology 2005;64:866-71.

13. Beauchet $\mathrm{O}$. Testosterone and cognitive function: current clinical evidence of a relationship. Eur J Endocrinol. 2006;155:773-81.

14. Folstein MF, Folstein SE, McHugh PR. "Mini-Mental State": a practical method for grading the cognitive state of patients for the clinician. J Psychiatr Res. 1975;12:189-98. 
15. Neale R, Brayne C, Johnson AL. Cognition and survival: an exploratiom in a large multicentre study of the populatiom aged 65 years and over. Int J Epidemiol. 2001;30:1383-8.

16. Tenover JS. Declining testiscular function in aging men. Int J Impotence Rese. 2003;15(Supp14):S3-S8.

17. Barret-Connor E, Goodman-Gruen D, Patay B. Endogenous sex hormones and cognitive function in older men. J Clin Endocrinol Metab. 1999;84:3681-5.
18. Yaffe K, Lui L-Y, Zmuda J, Cauley J. Sex hormones and cognitive function in older men. J Am Geriatrics Soc. 2002;50:707-12.

19. Yeap BB, Almeida OP, Hyde Z, Paul Chubb SA, Hankey GJ, Jamrozik K, et al. Higher serum free testosterone is associated with better cognitive function in older men, while total testosterone is not. The Health In Men Study. Clin Endocrinol 2008;68:404-12. 